\title{
Geranium and Purple Fountain Grass Leaf Pigmentation Is Influenced by End-of-Production Supplemental Lighting with Red and Blue Light-emitting Diodes
}

\author{
W. Garrett Owen ${ }^{1}$ and Roberto G. Lopez ${ }^{1,2}$ \\ Department of Horticulture and Landscape Architecture, Purdue University, \\ 625 Agriculture Mall Drive, West Lafayette, IN 47907
}

Additional index words. anthocyanin, light quality, Pelargonium $\times$ hortorum, Pennisetum $\times$ advena, prior to shipping

\begin{abstract}
Under low-light greenhouse conditions, anthocyanin pigmentation in vegetative tissues of red- or purple-leafed floricultural crops is not fully expressed and, consequently, plants are not as visually appealing to consumers. Our objective was to quantify the effect of end-of-production (EOP; before shipping) supplemental lighting (SL) of different light sources, qualities, and intensities on foliage color of geranium (Pelargonium $\times$ hortorum L.H. Bailey 'Black Velvet') and purple fountain grass [Pennisetum $\times$ advena Wipff and Veldkamp (formerly known as Pennisetum setaceum Forsk. Chiov. 'Rubrum')]. Plants were finished under early (Expt. 1) and late (Expt. 2) seasonal greenhouse ambient solar light and provided with 16 hours of day-extension lighting from low-intensity light-emitting diode (LED) lamps [7:11:33:49 blue:green:red:far-red light ratio (\%); control] delivering $4.5 \mu \mathrm{mol} \cdot \mathrm{m}^{-2} \cdot \mathrm{s}^{-1}$, or 16 hours of EOP SL from highpressure sodium (HPS) lamps delivering $70 \mu \mathrm{mol} \cdot \mathrm{m}^{-2} \cdot \mathrm{s}^{-1}$, or LED arrays (100:0, 87:13, 50:50, or 0:100 red:blue) delivering $100 \mu \mathrm{mol} \cdot \mathrm{m}^{-2} \cdot \mathrm{s}^{-1}$, or 0:100 red:blue LEDs delivering 25 or $50 \mu \mathrm{mol} \cdot \mathrm{m}^{-2} \cdot \mathrm{s}^{-1}$. Geranium and fountain grass chlorophyll content and leaf color were estimated using a SPAD-502 chlorophyll meter and Minolta tristimulus colorimeter, respectively. Relative chlorophyll content (RCC) and foliage $L^{*}$ (lightness), $C^{*}$ (chroma; a measure of saturation), and $h^{\circ}$ (hue angle; a measure of tone) values were significantly influenced by EOP SL and days of exposure. Generally, RCC of geranium and fountain grass increased from 3 to 14 days of exposure to EOP SL from HPS lamps and LEDs delivering $100 \mu \mathrm{mol} \cdot \mathrm{m}^{-2} \cdot \mathrm{s}^{-1}$. Under low daily light integrals (DLIs) $\left[8.6 \mathrm{~mol} \cdot \mathrm{m}^{-2} \cdot \mathrm{d}^{-1}\right.$ (geranium) and $9.4 \mathrm{~mol} \cdot \mathrm{m}^{-2} \cdot \mathrm{d}^{-1}$ (purple fountain grass)] EOP SL providing $100 \mu \mathrm{mol} \cdot \mathrm{m}^{-2} \cdot \mathrm{s}^{-1}$ of $100: 0,87: 13,50: 50$, or $0: 100$ red:blue light for $\geq 14$ days resulted in lower $L^{*}$ (darker foliage), $C^{*}$ (saturated), and $h^{\circ}$ (orange to violet-red hues). Our data indicate that a minimum of 14 days of EOP SL providing $100 \mu \mathrm{mol} \cdot \mathrm{m}^{-2} \cdot \mathrm{s}^{-1}$ of 50:50 or 0:100 red:blue light enhanced foliage color of geranium and fountain grass leaves when plants were grown under a low greenhouse DLI $\leq 9 \mathrm{~mol} \cdot \mathrm{m}^{-2} \cdot \mathrm{d}^{-1}$.
\end{abstract}

In floriculture crops, aesthetic qualities, including flower and foliage color or variegation, influence consumers' initial perceptions

Received for publication 27 June 2016. Accepted for publication 19 Oct. 2016.

We gratefully acknowledge Rob Eddy, Wesley Randall, Kristine Binkley, Andrea Hilligoss, and Alyssa Myers for greenhouse assistance; and Judy Santini for experimental design and statistical consultation. We thank American Takii, Inc. for seed; Pleasant View Gardens, Inc. for plant material; Sun Gro Horticulture for substrate; Everris NA, Inc. for fertilizer; Philips Lighting, Hort Americas, and Orbital Technologies Corp. for LEDs; and the USDA-NIFA SCRI grant no. 2010-51181-21369 for funding.

The use of trade names in this publication does not imply endorsement by Purdue University or Michigan State University of products named or criticism of similar ones not mentioned.

${ }^{1}$ Current address: Department of Horticulture, Michigan State University, 1066 Bogue Street, East Lansing, MI 48824.

${ }^{2}$ Corresponding author. E-mail: rglopez@msu.edu. and thus, purchasing decisions. For instance, Berghage and Wolnick (2000) surveyed and reported that consumers have a definite preference for New Guinea impatiens (Impatiens hawkeri Bull.) with colored or variegated leaves, whereas solid green leaves were the least preferred. In addition, foliage with solid red upper or lower surfaces was preferred 2:1 over variegated foliage (Berghage and Wolnick, 2000). Color in reproductive and vegetative tissues is attributed to pigments, including chlorophylls, carotenoids, flavonoids, and anthocyanins (Lightbourn et al., 2008). Specifically, anthocyanins are responsible for the red, blue, or purple pigmentation in reproductive and vegetative tissues (Chalker-Scott, 1990). The concentration of anthocyanins in foliage is influenced by environmental conditions such as light quality, light intensity, and temperature (Oren-Shamir, 2009).

The influence of light on anthocyanin synthesis and accumulation (Beckwith et al.,
2004; Nguyen and Cin, 2009; Paradiso et al., 2011) and on the change of leaf color (Garland et al., 2010; Kim et al., 2012) has been previously investigated for several floriculture crop species. In general, induction of anthocyanin synthesis and accumulation requires high light intensities, as these pigments protect cells from high light damage by absorbing blue or ultraviolet light (Seigler, 1998). However, the majority of commercial bedding plant production occurs in late winter and early spring (Garland et al., 2010) when the ambient outdoor DLI is 15 to 35 $\mathrm{mol} \cdot \mathrm{m}^{-2} \cdot \mathrm{d}^{-1}$ (Korczynski et al., 2002). Inside the greenhouse, DLI is reduced by up to $50 \%$ or more from the greenhouse glazing material, superstructure, shading, and hanging baskets (Faust et al., 2005; Hanan, 1998; Peet, 1999; Warren et al., 1992). To address periods of low DLI inside the greenhouse, growers must decide whether to provide SL (Currey and Erwin, 2011). Most bedding plants are considered high quality when a DLI of 10 to $20 \mathrm{~mol} \cdot \mathrm{m}^{-2} \cdot \mathrm{d}^{-1}$ is provided during the finish stage of production (Faust, 2011). However, most greenhouses growers will provide a minimum target mean DLI of 10 to $12 \mathrm{~mol} \cdot \mathrm{m}^{-2} \cdot \mathrm{d}^{-1}$ that will result in acceptable quality bedding plants (Faust, 2011).

In recent years, studies have compared SL from HPS lamps and overhead LEDs for the production of floricultural crops. For example, Randall and Lopez (2015) reported 28-dold geranium 'Bullseye Red' seedlings to be of higher quality under SL from HPS lamps and LED arrays with a red:blue light ratio (\%) of $87: 13$ than under ambient light. In addition, plants exhibited dark-purple zonal leaf bands under LED SL and sole-source lighting (SSL). Other reports indicate that overhead LED arrays providing monochromatic or combinations of narrow-spectrum SL produced comparable or higher quality plants than HPS lamps (Bergstrand and Schüssler, 2012; Islam et al., 2012; Schamp et al., 2012; Terfa et al., 2013; Werner et al., 2011). In addition, several studies have reported increased anthocyanins or enhanced foliage color when plants were grown under LED arrays providing blue light. For example, Tarakanov et al. (2012) reported increased anthocyanin accumulation, chlorophyll content, and leaf pigmentation of coleus (Coleus blumei Benth. 'Fairway Mosaic') when plants were grown under a 18 -h photoperiod with SL from LEDs delivering a photosynthetic photon flux $(P P F)$ of $170 \mu \mathrm{mol} \cdot \mathrm{m}^{-2} \cdot \mathrm{s}^{-1}$ at a light ratio of $75: 25$ red:blue compared with plants grown under HPS lamps. Similarly, Terfa et al. (2013) analyzed the internal and external quality parameters of potted rose (Rosa $\times$ hybrida L. 'Toril') grown in the greenhouse under a 20 -h photoperiod and SL from HPS lamps or LEDs delivering a $P P F$ of $100 \mu \mathrm{mol} \cdot \mathrm{m}^{-2} \cdot \mathrm{s}^{-1}$ at a ratio of 80:20 red:blue light. They reported increased anthocyanin and chlorophyll content for LED-grown potted rose compared with HPS-grown plants (Terfa et al., 2013). However, little is known regarding the short-term 
use of LEDs to enhance foliage color and the aesthetic quality of floriculture crops. Recently, Owen and Lopez (2015) found 5 to $7 \mathrm{~d}$ of EOP (before harvest) SL from LEDs providing $100 \mu \mathrm{mol} \cdot \mathrm{m}^{-2} \cdot \mathrm{s}^{-1}$ of 100:0, 50:50, or 0:100 red:blue light for $16-\mathrm{h}$ increased foliage color of four varieties of red leaf lettuce (Lactuca sativa L. 'Cherokee', 'Magenta', 'Ruby Sky', and 'Vulcan'). Therefore, shortterm exposure of monochromatic or combinations of narrow spectrum SL from LEDs is a potential lighting application for bedding plant producers to enhance aesthetic qualities such as leaf color.

To our knowledge, no published information exists on EOP (before shipping) SL from LEDs to enhance leaf color of greenhousegrown geranium 'Black Velvet' or purple fountain grass. Therefore, the objective of this study was to quantify and compare the effects of EOP SL from HPS lamps to LEDs of different light intensities, light qualities, and days of exposure on the leaf color of two bedding plant species. The two species were chosen based on grower challenges during early spring to produce aesthetically appealing plants with vivid foliage color. In addition, they were selected based on foliage color and leaf morphologies. For geranium 'Black Velvet', leaves are reniform and vary from almost "zoned" to completely solid red to dark maroon centers with a contrasting green leaf margin, whereas purple fountain grass leaves are narrow, curving, linear blades that vary in color from dark to vivid red-purple. Therefore, foliage color is imperative for the aesthetic appeal and marketing of both bedding plants.

\section{Materials and Methods}

Plant material, culture, and propagation environment. On 25 Jan. (Expt. 1) and 26 Feb. 2014 (Expt. 2), seeds of geranium (Pelargonium $\times$ hortorum 'Black Velvet') (American Takii, Inc., Salinas, CA) were sown into 72 -cell plug trays $(30.7-\mathrm{mL}$ individual cell volume; Landmark Plastics, Akron, $\mathrm{OH}$ ) filled with a commercial soilless medium composed of (by volume) $65 \%$ peat, $20 \%$ perlite, and $15 \%$ vermiculite (Super Fine Germinating Mix; Sun Gro Horticulture, Agawam, MA). Seedlings were irrigated with acidified water supplemented with watersoluble fertilizer (Jack's LX 16N-0.94P12.3K Plug Formula for High Alkalinity Water; J.R. Peters, Inc., Allentown, PA) to provide the following $\left(\mathrm{mg} \cdot \mathrm{L}^{-1}\right)$ : nitrogen $(\mathrm{N}$; $100)$, phosphorous $(\mathrm{P} ; 5)$, potassium $(\mathrm{K} ; 78)$, calcium $(\mathrm{Ca} ; 18)$, magnesium $(\mathrm{Mg} ; 9.4)$, iron $(\mathrm{Fe} ; 0.50)$, manganese $(\mathrm{Mn} ; 0.25)$, zinc $(\mathrm{Zn}$; $0.25)$, boron $(\mathrm{B} ; 0.10)$, copper $(\mathrm{Cu} ; 0.05)$, and molybdenum (Mo; 0.05). Irrigation water was supplemented with $93 \%$ sulfuric acid (Brenntag, Reading, PA) at $0.08 \mathrm{ppm}$ to reduce alkalinity to $100 \mathrm{mg} \cdot \mathrm{L}^{-1}$ carbonate and $\mathrm{pH}$ to a range of 5.8 to 6.2 .

Seedlings were grown in a glass-glazed greenhouse at Purdue University, West Lafayette, IN (lat. $40^{\circ} \mathrm{N}$ ) with exhaust fan and evaporative-pad cooling, radiant hot water heating, and retractable shade curtains controlled by an environmental control system (Maximizer Precision 10; Priva Computers Inc., Vineland Station, ON, Canada). Amplified quantum sensors (SQ-212; Apogee Instruments, Inc., Logan, UT) measured $P P F$ every $15 \mathrm{~s}$ and the average of each sensor was logged every $15 \mathrm{~min}$ by a data logger (WD 2800; Spectrum Technologies, Inc., Aurora, IL). Air temperature was monitored and recorded by a separate aspirated Priva sensor (Maximizer Precision 10; Priva Computers Inc.). The greenhouse air temperature set point for Expts. 1 and 2 was a constant $20{ }^{\circ} \mathrm{C}$. The photoperiod was $16 \mathrm{~h}$ (0600 to $2200 \mathrm{HR}$ ) consisting of natural daylengths with day-extension lighting from HPS lamps (e-system HID; PARSource, Petaluma, CA) that delivered a supplemental $P P F$ of $\approx 70 \mu \mathrm{mol} \cdot \mathrm{m}^{-2} \cdot \mathrm{s}^{-1}$ at plant height. During plug culture, average daily temperature (ADT) and DLI for Expts. 1 and 2 were $19.3 \pm 1.8$ and $19.4 \pm 2.0^{\circ} \mathrm{C}$ and $11.3 \pm 1.1$ and $11.3 \pm 0.9 \mathrm{~mol} \cdot \mathrm{m}^{-2} \cdot \mathrm{d}^{-1}$, respectively.

On 19 Feb. (Expt. 1) and 23 Mar. (Expt. 2), geranium seedlings were transplanted into 15.2-cm (1.3-L) diameter containers (Dillen Plastics, Middlefield, OH). On 6 Feb. (Expt. 1) and 14 Mar. (Expt. 2), 50-deep cell plug trays (106.5-mL individual cell volume; East Jordan Plastics, East Jordan, MI) of purple fountain grass [Pennisetum $\times$ advena (formerly known as $P$. setaceum 'Rubrum')] were received from a commercial greenhouse supplier (Pleasant View Gardens, Loudon, $\mathrm{NH})$ and transplanted into $12.7-\mathrm{cm}(885-\mathrm{mL})$ diameter containers (ITML Horticultural Products, Middlefield, OH). Containers were filled with a commercial soilless medium composed of (by volume) $65 \%$ peat, $20 \%$ perlite, and 15\% vermiculite (Fafard 2; Sun Gro Horticulture). Plants were irrigated as necessary with acidified water supplemented with a combination of two water-soluble fertilizers $[3: 1$ mixture of $15 \mathrm{~N}-2.2 \mathrm{P}-12.5 \mathrm{~K}$ and $21 \mathrm{~N}-2.2 \mathrm{P}-16.6 \mathrm{~K}$, respectively; (Everris, Marysville, $\mathrm{OH})$ ] to provide the following (mg. $\left.\mathrm{L}^{-1}\right)$ : N (200), P (26), K (163), Ca (50), $\mathrm{Mg}(20), \mathrm{Fe}(1.0), \mathrm{Mn}(0.5), \mathrm{Zn}(0.5), \mathrm{Cu}$ (0.24), B (0.24), and Mo (0.1).

Geranium and fountain grass plants were grown under 50\% shadecloth (DeWitt Company, Sikeston, MO) to simulate a lowambient DLI $\left(<10 \mathrm{~mol} \cdot \mathrm{m}^{-2} \cdot \mathrm{d}^{-1}\right)$. The ADT and DLI for geranium culture during Expts. 1 and 2 were $20.7 \pm 2.5$ and $21.2 \pm 2.4^{\circ} \mathrm{C}$ and $6.0 \pm 2.8$ and $7.5 \pm 4.4 \mathrm{~mol} \cdot \mathrm{m}^{-2} \cdot \mathrm{d}^{-1}$, respectively. The ADT and DLI for fountain grass culture during Expts. 1 and 2 were $20.4 \pm 2.7$ and $21.2 \pm 2.7^{\circ} \mathrm{C}$ and $6.0 \pm 2.7$ and $7.2 \pm 4.2$ $\mathrm{mol} \cdot \mathrm{m}^{-2} \cdot \mathrm{d}^{-1}$, respectively.

EOP greenhouse environment and $S L$ treatments. On 1 Apr. (Expt. 1) and 24 Apr. (Expt. 2), geranium and fountain grass plants were moved to a glass-glazed greenhouse where the air temperature set point was a constant $22{ }^{\circ} \mathrm{C}$. Ten plants of each species were placed under a 16-h photoperiod consisting of either ambient solar light plus dayextension light (control; no EOP SL) or EOP
SL from 0600 to 2200 HR. Day-extension lighting consisted of two low-intensity LED lamps (7:11:33:49 blue:green:red:far-red; Philips GreenPower Flowering deep red/ white/far-red LED lamp; Koninklijke Philips Electronics N.V., The Netherlands). Supplemental light was delivered from a $150-\mathrm{W}$ HPS lamp (PL 2000; P.L. Light Systems Inc., Beamsville, ON, Canada) or one of six LED arrays (Orbital Technologies Corporation, Madison, WI; Koninklijke Philips Electronics N.V.) providing monochromatic red [100:0 red $(660 \mathrm{~nm})$ :blue $(460 \mathrm{~nm})]$, monochromatic blue ( $0: 100$ red:blue), or a combination of red and blue (87:13 or 50:50 red: blue) light at high or low intensities (Table 1). Spectral scans of the control and EOP SL treatments were taken at night at the beginning of each replication with a spectroradiometer (BLUE-Wave Miniature Spectrometer; StellarNet, Inc., Tampa, FL). Spectral quality of each light source is provided in Fig. 1. The use of $62 \%$ shadecloth (XLS 16-F; Ludvig Svensson, Inc., Charlotte, NC) served as a barrier between each EOP treatment to reduce the likelihood of light pollution. Amplified quantum sensors (SQ-110; Apogee Instruments, Inc.) measured solar $P P F$ every $15 \mathrm{~s}$ and the average of each sensor was logged every $15 \mathrm{~min}$ by a data logger (WD 2800; Spectrum Technologies, Inc.). For geranium, the ADT and average solar DLI after $14 \mathrm{~d}$ during Expts. 1 and 2 were $22.7 \pm$ 1.1 and $22.9 \pm 1.3^{\circ} \mathrm{C}$ and $8.6 \pm 5.0$ and $12.6 \pm$ $4.7 \mathrm{~mol} \cdot \mathrm{m}^{-2} \cdot \mathrm{d}^{-1}$, respectively. For fountain grass, the ADT and average solar DLI after $21 \mathrm{~d}$ during Expts. 1 and 2 were $22.7 \pm 1.1$ and $22.9 \pm 1.3^{\circ} \mathrm{C}$ and $9.4 \pm 4.2$ and $11.4 \pm 5.0$ $\mathrm{mol} \cdot \mathrm{m}^{-2} \cdot \mathrm{d}^{-1}$, respectively. The supplemental DLI for each treatment was calculated and is reported in Table 1.

Data collection. For geranium, at 0, 3, 5, 7 , and $14 \mathrm{~d}$ after initiating EOP SL, total chlorophyll $(\mathrm{a}+\mathrm{b})$ content (i.e., RCC) was estimated using a SPAD chlorophyll meter (SPAD-502; Konica Minolta Sensing, Inc., Osaka, Japan) by measuring two recently matured leaves of each plant under each lighting treatment. For fountain grass, RCC were repeatedly measured on the same two leaves at $0,3,5,7,14$, and $21 \mathrm{~d}$. Using the same two leaves previously mentioned for RCC, leaf color was measured for both species using a portable tristimulus colorimeter (CR-200; Konica Minolta Sensing, Inc.) equipped with a measuring head with a selfcontained light source that provided diffuse, uniform light over an 8-mm diameter measuring area. The analyzer was calibrated to a standard white reflective plate $\left(\mathrm{L}^{*}=97.5\right.$, $\left.\mathrm{a}^{*}=0.40, \mathrm{~b}^{*}=1.90\right)$ using the Commission Internationale de l'Eclairage (CIE) 1976 $\left(\mathrm{L}^{*} \mathrm{a}^{*} \mathrm{~b}^{*}\right)$ color coordinates. $\mathrm{L}^{*}$ values indicate darkness and lightness (black: $\mathrm{L}^{*}=0$; white: $\left.L^{*}=100\right)$. Chromametric $a^{*}$ values [ratio between greenness and redness (green: $\mathrm{a}^{*}=-60$; red: $\left.\left.\mathrm{a}^{*}=+60\right)\right]$ and chromametric $b^{*}$ values [ratio between blueness and yellowness (blue: $b^{*}=-60$; yellow: $a^{*}=$ $+60)$ ] were determined and used to calculate chroma $\left(\mathrm{C}^{*}\right)$ and hue angle $\left(h^{\circ}\right)$. 


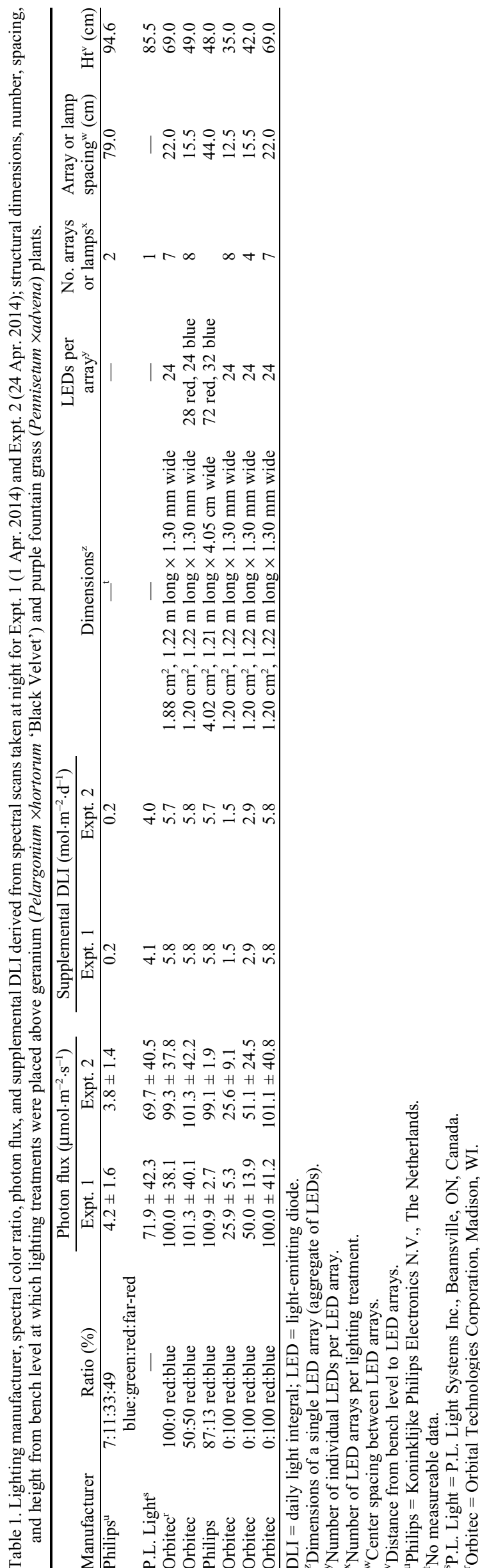

Chroma is a measure of saturation and was calculated as

$$
\mathrm{C}^{*}=\sqrt{a^{* 2}+b^{* 2}}
$$

On a circular scale, $h^{\circ}$, or tone, indicates redness $\left(0^{\circ}\right)$, yellowness $\left(90^{\circ}\right)$, greenness $\left(180^{\circ}\right)$, or blueness $\left(270^{\circ}\right)$ and was calculated as

$$
h^{\circ}=\tan ^{-1}\left(\frac{\mathrm{b}^{*}}{\mathrm{a}^{*}}\right)
$$

Statistical analysis. All plants for each species in Expts. 1 and 2 were grown under a common greenhouse environment, therefore, average $\mathrm{RCC}, \mathrm{L}^{*}, \mathrm{C}^{*}$, and $h^{\circ}$ values were similar before initiating EOP SL treatments $(0 \mathrm{~d})$. The experiment used a completely randomized design in a factorial arrangement. The factors were EOP SL treatment (eight levels) and days after lighting (four levels for geranium; five levels for fountain grass). Species were not compared. There were 10 plants per species (two individual samples per plant) per EOP SL treatment (20 samples per SL treatment). Interactions among EOP SL and days after lighting were not significant; therefore, main effects were reported. Effects of EOP SL and days after lighting were analyzed using SAS (version 9.2; SAS Institute, Cary, NC) mixed model procedure (PROC MIXED) for analysis of variance and means were separated by Fisher's least significant differences at $P \leq 0.05$. For RCC, data were not statistically different between experiments; therefore, data were pooled for each species.

\section{Results and Discussion}

Effects of EOP SL and days of exposure on $R C C$. End-of-production SL and days of exposure significantly influenced RCC of geranium and fountain grass (Table 2). At initiation $(0 \mathrm{~d})$, the average RCC of geranium and fountain grass was 48.4 and 35.3 , respectively. In general, for geranium, as days of exposure increased, RCC increased for all plants under each EOP SL treatment. For example, from 3 to $14 \mathrm{~d}$ of EOP SL delivering $100 \mu \mathrm{mol} \cdot \mathrm{m}^{-2} \cdot \mathrm{s}^{-1}$ provided by $100: 0,87: 13,50: 50$, and $0: 100$ red: blue light, RCC increased from 48.8 to 62.0 , 49.4 to $61.7,48.5$ to 63.1 , and 44.6 to 62.2 (Table 2), respectively. Compared with no EOP SL (control), RCC of geranium was significantly higher under LED EOP SL delivering $100 \mu \mathrm{mol} \cdot \mathrm{m}^{-2} \cdot \mathrm{s}^{-1}$. Similarly, Owen and Lopez (2015) reported $14 \mathrm{~d}$ of EOP SL delivering $100 \mu \mathrm{mol} \cdot \mathrm{m}^{-2} \cdot \mathrm{s}^{-1}$ provided by $100: 0,0: 100$, or 50:50 red:blue light, resulted in increased RCC from 29.6 to 32.8 and 26.5 to 29.0 for lettuce 'Cherokee' and 'Ruby Sky' plants, respectively, compared with the control.

For fountain grass, regardless of EOP SL source, RCC significantly increased up to $14 \mathrm{~d}$ after exposure to EOP SL; however, an additional $7 \mathrm{~d}(21 \mathrm{~d})$ of exposure to EOP SL resulted in no significant differences (Table 2). For instance, 14 and $21 \mathrm{~d}$ of EOP SL resulted in RCC of 38.4 and 38.7, 


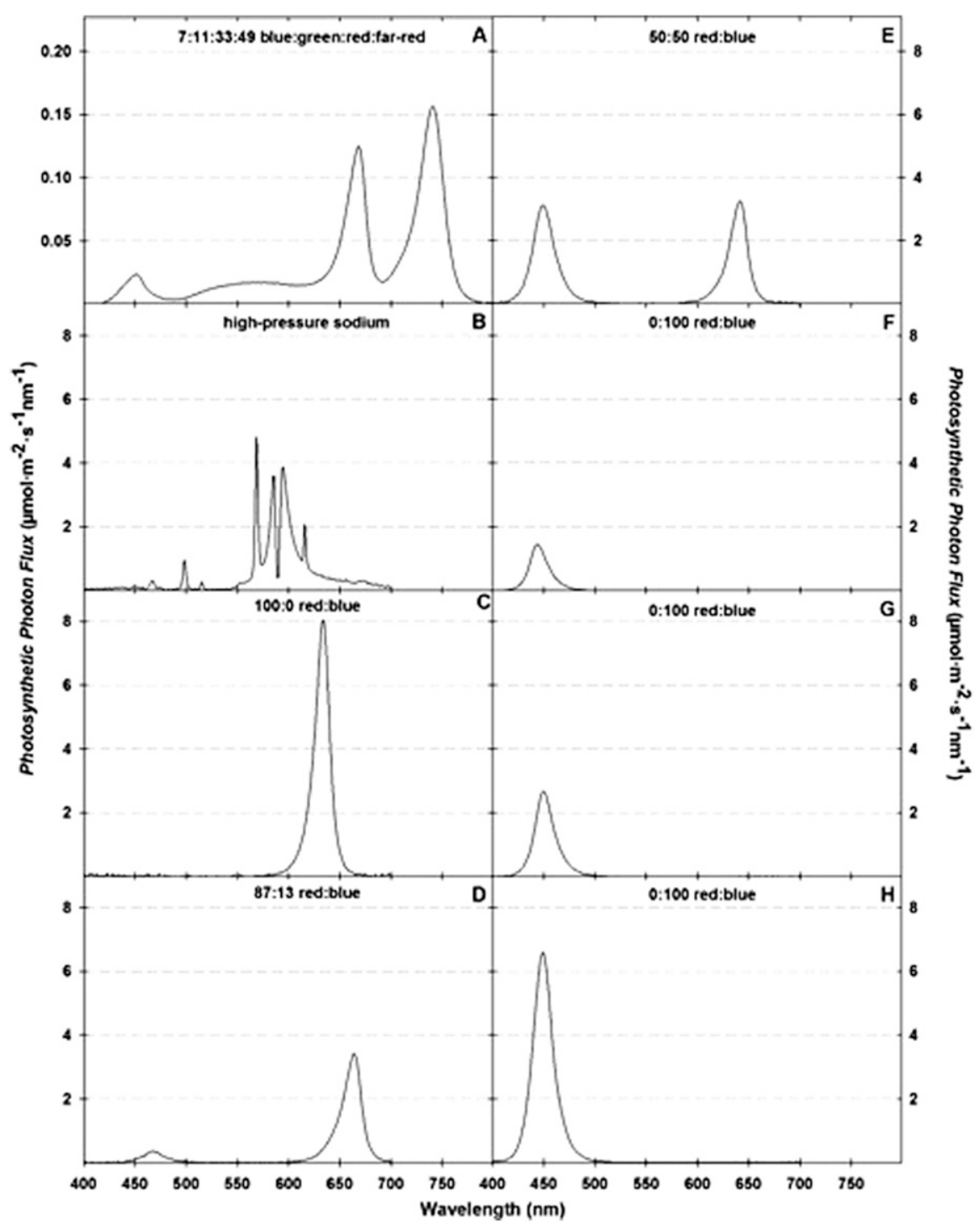

Fig. 1. (A-H) Spectral quality of $4.5 \mu \mathrm{mol} \cdot \mathrm{m}^{-2} \cdot \mathrm{s}^{-1}$ delivered from day-extension low-intensity lightemitting diode (LED) lamps. (A) 7:11:33:49 blue:green:red:far-red light ratio (\%); control, (B) 70 $\mu \mathrm{mol} \cdot \mathrm{m}^{-2} \cdot \mathrm{s}^{-1}$ delivered from high-pressure sodium lamps or (C) LED arrays delivering $100 \mu \mathrm{mol} \cdot \mathrm{m}^{-2} \cdot \mathrm{s}^{-1}$ of 100:0 red:blue, (D) $100 \mu \mathrm{mol} \cdot \mathrm{m}^{-2} \cdot \mathrm{s}^{-1}$ of $87: 13 \mathrm{red}$ :blue, (E) $100 \mu \mathrm{mol} \cdot \mathrm{m}^{-2} \cdot \mathrm{s}^{-1}$ of $50: 50 \mathrm{red}:$ blue, (F) $25 \mu \mathrm{mol} \cdot \mathrm{m}^{-2} \cdot \mathrm{s}^{-1}$ of $0: 100$ red:blue, (G) $50 \mu \mathrm{mol} \cdot \mathrm{m}^{-2} \cdot \mathrm{s}^{-1}$ of $0: 100 \mathrm{red}:$ blue, or (H) $100 \mu \mathrm{mol} \cdot \mathrm{m}^{-2} \cdot \mathrm{s}^{-1}$ of 0:100 red:blue end-of-production supplemental light.

respectively, when fountain grass was finished under $70 \mu \mathrm{mol} \cdot \mathrm{m}^{-2} \cdot \mathrm{s}^{-1}$ delivered from a HPS lamp. Owen and Lopez (2015) also reported that an additional $2 \mathrm{~d}$ (from 5 to $7 \mathrm{~d}$ ) of 50:50 red:blue EOP SL delivering 100 $\mu \mathrm{mol} \cdot \mathrm{m}^{-2} \cdot \mathrm{s}^{-1}$ did not significantly influence RCC of lettuce 'Vulcan' plants. However, in the present study, increasing proportions of blue light significantly increased RCC. For example, $14 \mathrm{~d}$ of EOP SL resulted in RCC of $34.9,37.7,39.4$, and 41.3 when fountain grass was finished under $100 \mu \mathrm{mol} \cdot \mathrm{m}^{-2} \cdot \mathrm{s}^{-1}$ delivered from 100:0, 87:13, 50:50, and $0: 100$ red:blue light, respectively.

The intensity and distribution of chlorophylls and anthocyanins are known to contribute to leaf color (Gazula et al., 2007). Environmental factors such as light quantity, quality, and duration and temperature can strongly influence the accumulation of these pigments (Owen and Lopez, 2015). In the present et al., 2005). Instrumentally, the measurement of anthocyanin and chlorophyll concentrations by chemical extractions has been previously used to determine foliage color of several ornamental crops (Beckwith et al., 2004; Brand, 1997; Kim et al., 2012; Wang et al., 2005). However, anthocyanin and chlorophyll extractions are destructive, time consuming, and not favorable for repeated measures. Alternatively, nondestructive instrumental measurements can measure chlorophyll content and foliage color. For instance, Wang et al. (2005) demonstrated that a SPAD meter could be used as a nondestructive instrumental quality assessment of 10 ornamental green-leaved foliage plants.

Tristimulus colorimeters can be used to determine and track changes in foliage color. For instance, Brand (1997), Kim et al. (2012), and Owen and Lopez (2015) used colorimeters to measure foliage color of mountain laurel (Kalmia latifolia L.), polka dot plant (Hypoestes phyllostachya Baker) and English ivy (Hedera helix L. 'Golden Ingot'), and red leaf lettuce varieties, respectively. Furthermore, Madeira et al. (2003) and Gazula et al. (2007) reported significant correlations between leaf color, tristimulus colorimeter readings, and increased anthocyanin concentration when nondestructive instrumental assessments were performed on sweet pepper (Capsicum annuum L. 'Capistrano') and lettuce leaf color, respectively. Therefore, nondestructive colorimetric assessments can be used to determine and track leaf color without damaging leaves or plants (Owen and Lopez, 2015).

Effects of seasonal DLI on foliage color. Average leaf lightness $\left(\mathrm{L}^{*}\right)$ and chroma $\left(\mathrm{C}^{*}\right)$ values and hue angle $\left(h^{\circ}\right)$ of geranium at initiation $(0 \mathrm{~d})$ of Expt. 1 (DLI $\leq 9 \mathrm{~mol} \cdot \mathrm{m}^{-2} \cdot \mathrm{d}^{-1}$ ) were 32.9 and 10.1 CIELAB units and $117.9^{\circ}$, respectively, indicating very dark grayish green foliage. Meanwhile, at initiation $(0 \mathrm{~d})$ of Expt. 2 (DLI $\geq 11 \mathrm{~mol} \cdot \mathrm{m}^{-2} \cdot \mathrm{d}^{-1}$ ), average $\mathrm{L}^{*}$ and $\mathrm{C}^{*}$ values and $h^{\circ}$ were 33.6 and 10.2 CIELAB units and $106.3^{\circ}$, respectively, also indicating very dark grayish yellow foliage. For fountain grass at initiation $(0 \mathrm{~d})$ of Expt. 1, average $\mathrm{L}^{*}$ and $\mathrm{C}^{*}$ values and $h^{\circ}$ were 35.5 and $12.7 \mathrm{CIELAB}$ units and $120.4^{\circ}$, indicating pale green foliage. Similarly, under an average DLI of $7.0 \mathrm{~mol} \cdot \mathrm{m}^{-2} \cdot \mathrm{d}^{-1}$, Beckwith et al. (2004) reported fountain grass foliage color of greenhouse-grown plants had light-purple foliage from midleaf to tip, were mostly purple at the top of the canopy, and appeared mostly green in color at the bottom and middle of the canopy. At initiation $(0 \mathrm{~d})$ of Expt. 2, average $\mathrm{L}^{*}$ and $\mathrm{C}^{*}$ values and $h^{\circ}$ of fountain grass were 30.5 and 6.4 CIELAB units and $81.7^{\circ}$, respectively, indicating slightly green foliage.

In the current study, DLI during Expt. 1 $\left(\mathrm{DLI} \leq 9 \mathrm{~mol} \cdot \mathrm{m}^{-2} \cdot \mathrm{d}^{-1}\right.$ ) and Expt. 2 (DLI $\geq$ $11 \mathrm{~mol} \cdot \mathrm{m}^{-2} \cdot \mathrm{d}^{-1}$ ) influenced foliage color of geranium and fountain grass. In general, EOP SL and days of exposure significantly influenced $\mathrm{L}^{*}$ and $\mathrm{C}^{*}$ values and $h^{\circ}$ of geranium (Table 3 ) and fountain grass (Table 4) when plants were finished under a mean DLI $\leq 9$ 
Table 2. Average relative chlorophyll content (RCC) of geranium (Pelargonium $\times$ hortorum 'Black Velvet') and purple fountain grass (Pennisetum $\times$ advena) plants finished under a seasonal daily light integral (DLI) $\leq 9 \mathrm{~mol} \cdot \mathrm{m}^{-2} \cdot \mathrm{d}^{-1}$ (Expt. $1 ; 1 \mathrm{Apr}$. 2014) and DLI $\geq 11 \mathrm{~mol} \cdot \mathrm{m}^{-2} \cdot \mathrm{d}^{-1}$ (Expt. 2; 24 Apr. 2014) achieved by using ambient solar light with $16 \mathrm{~h}$ of day-extension lighting from low-intensity light-emitting diode (LED) lamps [7:11:33:49 blue:green:red:far-red light ratio (\%); control] delivering $4.5 \mu \mathrm{mol} \cdot \mathrm{m}^{-2} \cdot \mathrm{s}^{-1}$, or $16 \mathrm{~h}$ of supplemental light (SL) from high-pressure sodium (HPS) lamps delivering $70 \mu \mathrm{mol} \cdot \mathrm{m}^{-2} \cdot \mathrm{s}^{-1}$, or LED arrays delivering $100 \mu \mathrm{mol} \cdot \mathrm{m}^{-2} \cdot \mathrm{s}^{-1}$ of 100:0 red:blue, $100 \mu \mathrm{mol} \cdot \mathrm{m}^{-2} \cdot \mathrm{s}^{-1}$ of $87: 13$ red:blue, $100 \mu \mathrm{mol} \cdot \mathrm{m}^{-2} \cdot \mathrm{s}^{-1}$ of $50: 50$ red:blue, or 25,50 , or $100 \mu \mathrm{mol} \cdot \mathrm{m}^{-2} \cdot \mathrm{s}^{-1}$ 0:100 red:blue end-of-production (EOP) SL from 3 to $14 \mathrm{~d}$ after initiation of EOP lighting treatments.

\begin{tabular}{|c|c|c|c|c|c|c|c|c|}
\hline \multirow[b]{3}{*}{ Days $^{z}$} & \multicolumn{8}{|c|}{ Light source } \\
\hline & Control & HPS & 100:0 red:blue & $87: 13$ red:blue & 50:50 red:blue & & 0:100 red:blu & \\
\hline & 4.5 & 70.0 & 100.0 & 100.0 & 100.0 & 25.0 & 50.0 & 100.0 \\
\hline 3 & $49.6 \mathrm{C}^{\mathrm{x}} a b^{\mathrm{w}}$ & $50.0 \mathrm{Da}$ & $48.8 \mathrm{Dab}$ & 49.4 Dab & 48.5 Dab & 48.6 Dab & $47.5 \mathrm{Db}$ & $44.6 \mathrm{Dc}$ \\
\hline 5 & $50.5 \mathrm{BCa}$ & $52.5 \mathrm{Ca}$ & $51.4 \mathrm{Ca}$ & $51.8 \mathrm{Ca}$ & $51.3 \mathrm{Ca}$ & $52.6 \mathrm{Ca}$ & $50.9 \mathrm{Ca}$ & $46.1 \mathrm{Cb}$ \\
\hline 7 & $53.1 \mathrm{Bbc}$ & $54.6 \mathrm{Bab}$ & $54.9 \mathrm{Bab}$ & $56.1 \mathrm{Ba}$ & $55.0 \mathrm{Bab}$ & 54.7 Bab & $54.2 \mathrm{Bab}$ & $50.9 \mathrm{Bc}$ \\
\hline 3 & $35.8 \mathrm{Ba}$ & $34.9 \mathrm{Cab}$ & $31.4 \mathrm{Bd}$ & $32.9 \mathrm{Ccd}$ & 34.1 Dbc & $33.7 \mathrm{Dbc}$ & $32.0 \mathrm{Cd}$ & 33.7 Dbc \\
\hline 5 & $36.4 \mathrm{Ba}$ & $36.6 \mathrm{Ba}$ & $32.4 \mathrm{Bd}$ & $33.8 \mathrm{BCcd}$ & $35.6 \mathrm{Cab}$ & $34.7 \mathrm{Cbc}$ & $32.6 \mathrm{Cb}$ & $35.4 \mathrm{Cb}$ \\
\hline 7 & $36.9 \mathrm{Ba}$ & $36.4 \mathrm{Ba}$ & $32.0 \mathrm{Bc}$ & $34.8 \mathrm{Bb}$ & $37.1 \mathrm{Ba}$ & 35.6 Bab & $34.1 \mathrm{Bb}$ & 36.7 Ba \\
\hline 14 & $38.7 \mathrm{Abc}$ & $38.4 \mathrm{Abc}$ & $34.9 \mathrm{Ae}$ & 37.7 Acd & $39.4 \mathrm{Ab}$ & 36.2 Ade & $35.5 \mathrm{Ae}$ & $41.3 \mathrm{Aa}$ \\
\hline 21 & $38.9 \mathrm{Abc}$ & $38.7 \mathrm{Abc}$ & $35.7 \mathrm{Ad}$ & $38.6 \mathrm{Abc}$ & $39.6 \mathrm{Ab}$ & $38.0 \mathrm{Ac}$ & 36.2 Ad & 42.3 Aa \\
\hline
\end{tabular}

Means were not statistically different between experiments; therefore, data were pooled for each species.

$P P F=$ photosynthetic photon flux.

${ }^{\mathrm{z}}$ Days of exposure to the control or EOP SL.

${ }^{\mathrm{y}} \mathrm{RCC}$ [total chlorophyll $(\mathrm{a}+\mathrm{b})$ ] was estimated using a SPAD chlorophyll meter.

${ }^{\mathrm{x}}$ Within-column means followed by different upper case letters are significantly different by Fisher's least significant differences (LSD) at $P \leq 0.05$.

${ }^{\text {w}}$ Within-row means followed by different lower case letters are significantly different by Fisher's LSD at $P \leq 0.05$.

$\mathrm{mol} \cdot \mathrm{m}^{-2} \cdot \mathrm{d}^{-1}$ and displayed little to no significance under a DLI $\geq 11 \mathrm{~mol} \cdot \mathrm{m}^{-2} \cdot \mathrm{d}^{-1}$. This provides initial evidence that EOP SL is most effective when plants are finished under a low greenhouse DLI of $<10 \mathrm{~mol} \cdot \mathrm{m}^{-2} \cdot \mathrm{d}^{-1}$. Furthermore, the parameters mentioned here to quantify and track foliage color support previous investigations regarding the influence of DLI on coloration and quality of floriculture crops (Garland et al., 2010; Kim et al., 2012). For instance, Garland et al. (2010) reported coleus [Solenostemon scutellarioides (L.) Codd 'Kong Red' and 'Wizard Coral Sunrise'] grown at DLIs $<5.8 \mathrm{~mol} \cdot \mathrm{m}^{-2} \cdot \mathrm{d}^{-1}$ for 8 weeks exhibited more green coloration and less burgundy and coral variegations, and plants were considered to be of low quality. Under SSL, Beckwith et al. (2004) found that a DLI of 0.6 to $6.5 \mathrm{~mol} \cdot \mathrm{m}^{-2} \cdot \mathrm{d}^{-1}$ (3 to $160 \mu \mathrm{mol} \cdot \mathrm{m}^{-2} \cdot \mathrm{s}^{-1}$ for a $24-\mathrm{h}$ photoperiod), provided by white fluorescent lamps, promoted anthocyanin pigment development and accumulation in the first $48 \mathrm{~h}$, uniform pigmentation of the leaf surface at $3 \mathrm{~d}$, and dark purple leaf color after $7 \mathrm{~d}$. From this study, they concluded that fluorescent SL in the greenhouse may be useful for improving the color and aesthetic value of fountain grass. Therefore, although previous studies have documented the effect of DLI on foliage color of ornamental crops, they have not investigated the influence of light quality or the duration of SL for plants to develop leaf variegation and coloration.

Effects of seasonal DLI on $L^{*}$. For geranium, as exposure to EOP SL increased from 3 to $14 \mathrm{~d}$ under a mean DLI $\leq 9 \mathrm{~mol} \cdot \mathrm{m}^{-2} \cdot \mathrm{d}^{-1}$, $\mathrm{L}^{*}$ decreased, indicating darker leaves, under all EOP treatments (Fig. 2), whereas $\mathrm{L}^{*}$ values of plants finished under a mean DLI of $\geq 11 \mathrm{~mol} \cdot \mathrm{m}^{-2} \cdot \mathrm{d}^{-1}$ exhibited fewer significant changes. For example, geranium exposed to as little as $3 \mathrm{~d}$ of $100 \mu \mathrm{mol} \cdot \mathrm{m}^{-2} \cdot \mathrm{s}^{-1}$ of $50: 50$ or 0:100 red:blue light under a mean DLI $\leq$ $9 \mathrm{~mol} \cdot \mathrm{m}^{-2} \cdot \mathrm{d}^{-1}$ resulted in darker leaves (Table 3 ). After $14 \mathrm{~d}$ of EOP SL providing 100:0, 50:50, or $0: 100$ red:blue light delivering $100 \mu \mathrm{mol} \cdot \mathrm{m}^{-2} \cdot \mathrm{s}^{-1}$ under a mean DLI $\leq 9 \mathrm{~mol} \cdot \mathrm{m}^{-2} \cdot \mathrm{d}^{-1}, \mathrm{~L}^{*}$ values decreased from 31.0 to $26.8,29.6$ to 27.2 , and 30.4 to 26.8 CIELAB units, respectively (Table 3). Furthermore, the lowest $\mathrm{L}^{*}$ values (darkest leaves) were measured at $14 \mathrm{~d}$ of EOP SL delivering $100 \mu \mathrm{mol} \cdot \mathrm{m}^{-2} \cdot \mathrm{s}^{-1}$ provided by 100:0 (26.8 CIELAB units) or $0: 100$ (26.8 CIELAB units) red:blue light compared with those determined for the control (28.2 CIELAB units) and HPS lamp (28.4 CIELAB units). Maximum foliage darkness was achieved $7 \mathrm{~d}$ faster under $100 \mu \mathrm{mol} \cdot \mathrm{m}^{-2} \cdot \mathrm{s}^{-1}$ of $100: 0$ or $87: 13$ red:blue light than under 50:50 or 0:100 red:blue LEDs providing a similar $P P F$ (Fig. 2). Conversely, Owen and Lopez (2015) reported $100 \mu \mathrm{mol} \cdot \mathrm{m}^{-2} \cdot \mathrm{s}^{-1}$ of 50:50 red:blue EOP SL darkened (lower $\left.L^{*}\right)$ leaves of lettuce 'Ruby Sky' 7 d earlier than 100:0 and 0:100 red:blue EOP SL providing a similar $P P F$. In the current study, as little as $7 \mathrm{~d}$ of $50 \mu \mathrm{mol} \cdot \mathrm{m}^{-2} \cdot \mathrm{s}^{-1}$ of $0: 100 \mathrm{red}$ : blue light resulted in comparable foliage darkness compared with plants exposed to $100 \mu \mathrm{mol} \cdot \mathrm{m}^{-2} \cdot \mathrm{s}^{-1}$ of 100:0, 87:13, 50:50, or 0:100 red:blue EOP SL (Table 3 ). However, $14 \mathrm{~d}$ of EOP SL providing 0:100 red:blue light delivering $100 \mu \mathrm{mol} \cdot \mathrm{m}^{-2} \cdot \mathrm{s}^{-1}$ under a mean DLI $\geq 11 \mathrm{~mol} \cdot \mathrm{m}^{-2} \cdot \mathrm{d}^{-1}$ decreased $\mathrm{L}^{*}$ values of geranium from 30.9 to 28.0 CIELAB units compared with the control (31.9 to 31.4 CIELAB units).

For fountain grass, as exposure to EOP SL increased from 3 to $21 \mathrm{~d}$, L* values decreased (leaves darkened) under all EOP SL treatments (Fig. 3). For example, during Expt. 1, from 3 to $21 \mathrm{~d}$ of no EOP SL (control) or EOP SL providing 50:50 or 0:100 red:blue light delivering $100 \mu \mathrm{mol} \cdot \mathrm{m}^{-2} \cdot \mathrm{s}^{-1}, \mathrm{~L}^{*}$ values decreased from 35.5 to $31.4,34.3$ to 27.7 , and 30.0 to 28.1 CIELAB units, respectively. However, $100 \mu \mathrm{mol} \cdot \mathrm{m}^{-2} \cdot \mathrm{s}^{-1}$ of EOP SL providing 0:100 red:blue light resulted in significantly decreased $\mathrm{L}^{*}$ values (darker foliage) $7 \mathrm{~d}$ earlier compared with those under 50:50 red:blue light. Therefore, $>50 \%$ blue light hastened decreases in $L^{*}$ values. Conversely, Owen and Lopez (2015) reported a mean DLI of $6.8 \mathrm{~mol} \cdot \mathrm{m}^{-2} \cdot \mathrm{d}^{-1}$ and $100 \mu \mathrm{mol} \cdot \mathrm{m}^{-2} \cdot \mathrm{s}^{-1}$ of EOP SL providing 50:50 red:blue light to significantly decrease $L^{*}$ values of lettuce 'Cherokee', 'Magenta', and 'Ruby Sky' plants within $3 \mathrm{~d}$ compared with those under 100:0 or 0:100 red:blue light.

Under a mean DLI $\geq 11 \mathrm{~mol} \cdot \mathrm{m}^{-2} \cdot \mathrm{d}^{-1}$, exposure to EOP SL from 3 to $14 \mathrm{~d}$ resulted in decreasing $\mathrm{L}^{*}$ values (darkened leaves) for fountain grass plants under all LED EOP SL treatments. For example, from 3 to $14 \mathrm{~d}, \mathrm{~L}^{*}$ values of plants under $100 \mu \mathrm{mol} \cdot \mathrm{m}^{-2} \cdot \mathrm{s}^{-1}$ of EOP SL delivered from 100:0, 87:13, 50:50, or $0: 100$ red:blue light decreased from 29.4 to $28.0,29.6$ to $28.2,28.8$ to 27.7 , and 28.9 to 27.0 CIELAB units, respectively. However, $\mathrm{L}^{*}$ of fountain grass was found to be similar at $14 \mathrm{~d}$ when plants were exposed to $0: 100$, $87: 13$, 50:50, or $0: 100$ red:blue EOP SL delivering $100 \mu \mathrm{mol} \cdot \mathrm{m}^{-2} \cdot \mathrm{s}^{-1}$ compared with all other EOP SL treatments. Therefore, $\mathrm{L}^{*}$ was not influenced by light quality, but rather, by light intensity.

Effects of seasonal DLI on $C^{*}$. Under a mean DLI $\leq 9 \mathrm{~mol} \cdot \mathrm{m}^{-2} \cdot \mathrm{d}^{-1}$, increased $\mathrm{C}^{*}$ (saturation) of geranium foliage occurred $7 \mathrm{~d}$ earlier when plants were finished under 100 $\mu \mathrm{mol} \cdot \mathrm{m}^{-2} \cdot \mathrm{s}^{-1}$ of LED EOP SL delivering $\geq 13 \%$ blue light compared with no EOP SL (control) and all other EOP SL treatments. For example, $7 \mathrm{~d}$ of $100 \mu \mathrm{mol} \cdot \mathrm{m}^{-2} \cdot \mathrm{s}^{-1} \mathrm{de}-$ livered from $87: 13,50: 50$, or $0: 100$ red:blue 
Table 3. Average leaf lightness $\left(\mathrm{L}^{*}\right)$, chroma $\left(\mathrm{C}^{*}\right)$, and hue angle $\left(h^{\circ}\right)$ values of geranium (Pelargonium $\times$ hortorum 'Black Velvet') plants finished under a seasonal daily light integral (DLI) $\leq 9 \mathrm{~mol} \cdot \mathrm{m}^{-2} \cdot \mathrm{d}^{-1}$ (Expt. $1 ; 1 \mathrm{Apr}$. 2014) or DLI $\geq 11 \mathrm{~mol} \cdot \mathrm{m}^{-2} \cdot \mathrm{d}^{-1}$ (Expt. 2; 24 Apr. 2014) achieved by using ambient solar light with $16 \mathrm{~h}$ of day-extension lighting from low-intensity light-emitting diode (LED) lamps [7:11:33:49 blue:green:red:far-red light ratio (\%); control] delivering $4.5 \mu \mathrm{mol} \cdot \mathrm{m}^{-2} \cdot \mathrm{s}^{-1}$, or $16 \mathrm{~h}$ of supplemental light (SL) from high-pressure sodium (HPS) lamps delivering $70 \mu \mathrm{mol} \cdot \mathrm{m}^{-2} \cdot \mathrm{s}^{-1}$, or LED arrays delivering $100 \mu \mathrm{mol} \cdot \mathrm{m}^{-2} \cdot \mathrm{s}^{-1}$ of 100:0 red:blue, $100 \mu \mathrm{mol} \cdot \mathrm{m}^{-2} \cdot \mathrm{s}^{-1}$ of $87: 13$ red:blue, $100 \mu \mathrm{mol} \cdot \mathrm{m}^{-2} \cdot \mathrm{s}^{-1}$ of 50:50 red:blue, or 25,50 , or $100 \mu \mathrm{mol} \cdot \mathrm{m}^{-2} \cdot \mathrm{s}^{-1} 0: 100 \mathrm{red}: \mathrm{blue}$ endof-production (EOP) SL from 3 to $14 \mathrm{~d}$ after initiation of EOP lighting treatments.

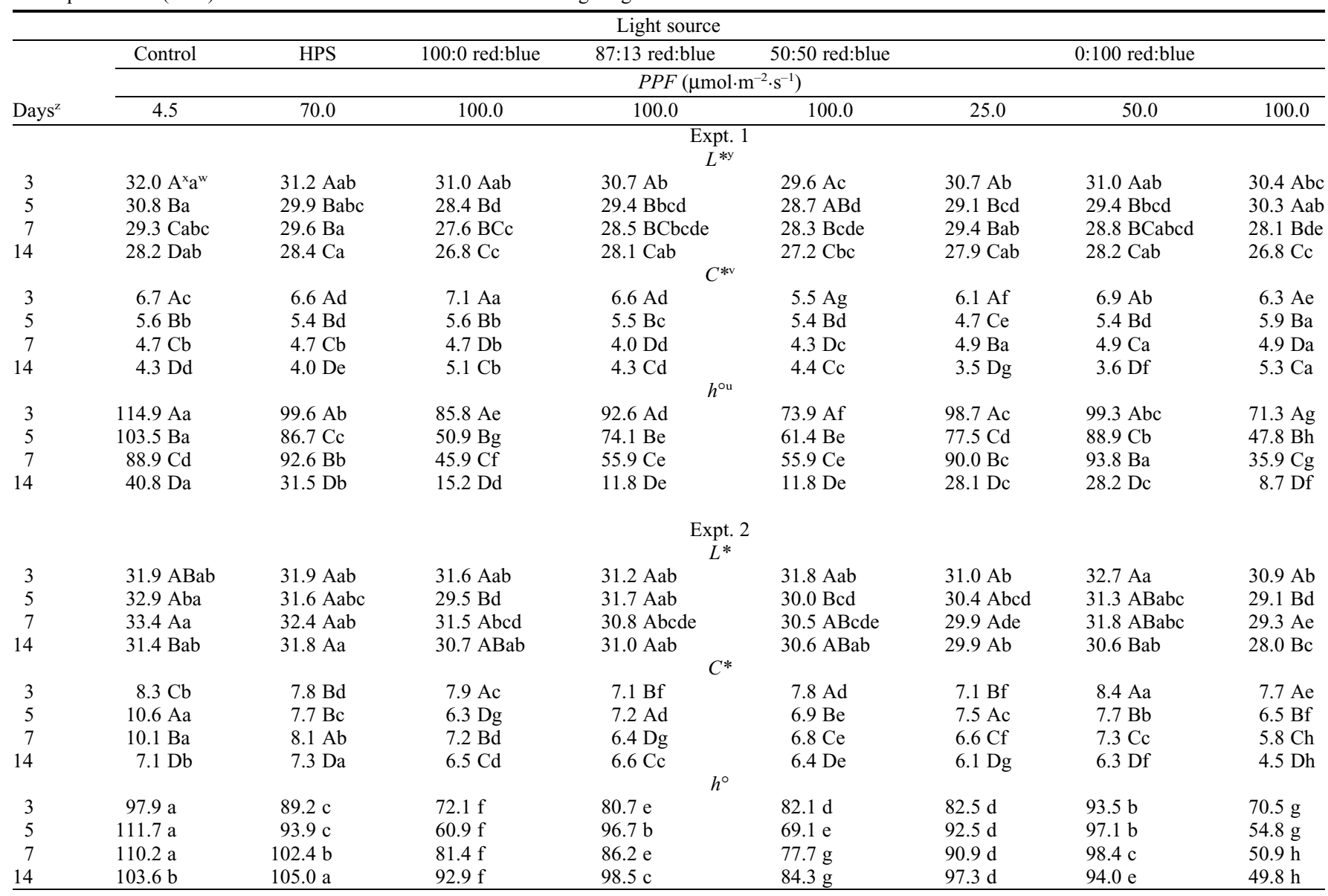

$P P F=$ photosynthetic photon flux.

${ }^{\mathrm{z}}$ Days of exposure to the control or EOP SL.

${ }^{y}$ Leaf lightness $\left(L^{*}\right)$ indicate darkness and lightness (black: $L^{*}=0$; white: $L^{*}=100$ ).

${ }^{\mathrm{x}}$ Within-column means followed by different upper case letters are significantly different by Fisher's least significant differences (LSD) at $P \leq 0.05$.

${ }^{\text {w}}$ Within-row means followed by different lower case letters are significantly different by Fisher's LSD at $P \leq 0.05$.

${ }^{\mathrm{v}}$ Chroma $\left(\mathrm{C}^{*}\right)$ calculated by Eq. [1].

"Hue angle $\left(h^{\circ}\right)$ calculated by Eq. [2].

EOP SL resulted in $\mathrm{C}^{*}$ values of $4.0,4.3$, or 4.9 CIELAB units, respectively (Table 2). Conversely, under LED SSL, Gangadhar et al. (2012) reported $\mathrm{C}^{*}$ of pepper 'Cheonyang' fruit to be similar when plants were grown under 50:50 and 0:100 red:blue light compared with 100:0 red:blue LED SSL delivering $70 \mu \mathrm{mol} \cdot \mathrm{m}^{-2} \cdot \mathrm{s}^{-1}$ to achieve a DLI of $4 \mathrm{~mol} \cdot \mathrm{m}^{-2} \cdot \mathrm{d}^{-1}$.

Chroma of geranium finished under a mean DLI $\geq 11 \mathrm{~mol} \cdot \mathrm{m}^{-2} \cdot \mathrm{d}^{-1}$ was not influenced by EOP SL providing 100:0 and $87: 13$ red:blue delivering $100 \mu \mathrm{mol} \cdot \mathrm{m}^{-2} \cdot \mathrm{s}^{-1}$. Under a mean DLI of $\geq 11 \mathrm{~mol} \cdot \mathrm{m}^{-2} \cdot \mathrm{d}^{-1}$ EOP SL providing increased proportions (\%) of red light (100:0 and 87:13) hastened foliage saturation by 5 (100:0 red:blue) and $7 \mathrm{~d}$ (87:13 red:blue), compared with LED EOP SL providing $\geq 50 \%$ blue light (Table 3 ). At $14 \mathrm{~d}$ of $0: 100$ red:blue EOP SL increasing from 25 to $100 \mu \mathrm{mol} \cdot \mathrm{m}^{-2} \cdot \mathrm{s}^{-1}$ under a mean $\mathrm{DLI} \leq 9 \mathrm{~mol} \cdot \mathrm{m}^{-2} \cdot \mathrm{d}^{-1}, \mathrm{C}^{*}$ increased from 3.5 to 5.3 CIELAB units (increased leaf color saturation). However, under a mean DLI $\geq$ $11 \mathrm{~mol} \cdot \mathrm{m}^{-2} \cdot \mathrm{d}^{-1}, 14 \mathrm{~d}$ of $0: 100$ red:blue EOP SL providing $100 \mu \mathrm{mol} \cdot \mathrm{m}^{-2} \cdot \mathrm{s}^{-1}$ resulted in the greatest saturation (4.5 CIELAB units) compared with all other EOP treatments. Therefore, increased light intensity and light quality played a significant role in darkening and enhancing geranium foliage under lowlight greenhouse conditions, such as those at DLIs $\leq 9 \mathrm{~mol} \cdot \mathrm{m}^{-2} \cdot \mathrm{d}^{-1}$. These results are consistent with those reported by Kim et al. (2012) which found increasing DLIs of $\approx 0.2$, $0.4,0.8,3.9$, and $7.8 \mathrm{~mol} \cdot \mathrm{m}^{-2} \cdot \mathrm{d}^{-1}(P P F$ of $\approx 2.7,6.8,13.5,67.5$, and $\left.135 \mu \mathrm{mol} \cdot \mathrm{m}^{-2} \cdot \mathrm{s}^{-1}\right)$ provided by triband phosphor fluorescent lamps decreased C* of English ivy 'Golden Ingot'.

Fountain grass plants finished under 100 $\mu \mathrm{mol} \cdot \mathrm{m}^{-2} \cdot \mathrm{s}^{-1}$ of EOP SL delivered from 100:0, 87:13, 50:50, and 0:100 red:blue light under a mean DLI $\leq 9 \mathrm{~mol} \cdot \mathrm{m}^{-2} \cdot \mathrm{d}^{-1}$ exhibited more intense foliage color, thus resulting significantly lower $\mathrm{C}^{*}$ values (Table 4 ). Maximum saturation of fountain grass foliage occurred after $3 \mathrm{~d}$ when plants were exposed to $0: 100$ red:blue EOP SL delivering 100 $\mu \mathrm{mol} \cdot \mathrm{m}^{-2} \cdot \mathrm{s}^{-1}$. Over time, EOP SL providing $100 \mu \mathrm{mol} \cdot \mathrm{m}^{-2} \cdot \mathrm{s}^{-1}$ resulted in less saturated foliage color, whereas light provided by the control increased foliage color saturation. For example, $21 \mathrm{~d}$ of EOP SL resulted in $\mathrm{C}^{*}$ values of 2.7 to 5.8 CIELAB units for fountain grass under $100 \mu \mathrm{mol} \cdot \mathrm{m}^{-2} \cdot \mathrm{s}^{-1} \mathrm{de}-$ livered from 100:0, 87:13, 50:50, and 0:100 red:blue light. However, $\mathrm{C}^{*}$ values of fountain grass plant finished under a mean DLI $\geq$ $11 \mathrm{~mol} \cdot \mathrm{m}^{-2} \cdot \mathrm{d}^{-1}$ were not significantly influenced by EOP SL or days of exposure (Table 4). From 3 to $21 \mathrm{~d}, \mathrm{C}^{*}$ values of all fountain grass plants finished under no EOP SL (control) or EOP SL ranged from 3.9 to 6.3 CIELAB units, indicating saturated (very dark to dark) foliage color. 
Table 4. Average leaf lightness $\left(\mathrm{L}^{*}\right)$, chroma $\left(\mathrm{C}^{*}\right)$, and hue angle $\left(h^{\circ}\right)$ values of purple fountain grass (Pennisetum $\left.\times a d v e n a\right)$ plants finished under a seasonal daily light integral (DLI) $\leq 9 \mathrm{~mol} \cdot \mathrm{m}^{-2} \cdot \mathrm{d}^{-1}$ (Expt. 1; 1 Mar. 2014) or DLI $\geq 11 \mathrm{~mol} \cdot \mathrm{m}^{-2} \cdot \mathrm{d}^{-1}$ (Expt. 2; 24 Apr. 2014) achieved by using ambient solar light provided with $16 \mathrm{~h}$ of day-extension lighting from low-intensity light-emitting diode (LED) lamps [7:11:33:49 blue:green:red:far-red light ratio (\%); control] delivering $4.5 \mu \mathrm{mol} \cdot \mathrm{m}^{-2} \cdot \mathrm{s}^{-1}$, or $16 \mathrm{~h}$ of supplemental light (SL) from high-pressure sodium (HPS) lamps delivering $70 \mu \mathrm{mol} \cdot \mathrm{m}^{-2} \cdot \mathrm{s}^{-1}$, or LED arrays delivering $100 \mu \mathrm{mol} \cdot \mathrm{m}^{-2} \cdot \mathrm{s}^{-1}$ of $100: 0$ red:blue, $100 \mu \mathrm{mol} \cdot \mathrm{m}^{-2} \cdot \mathrm{s}^{-1}$ of $87: 13$ red:blue, $100 \mu \mathrm{mol} \cdot \mathrm{m}^{-2} \cdot \mathrm{s}^{-1}$ of 50:50 red:blue, or 25,50, or $100 \mu \mathrm{mol} \cdot \mathrm{m}^{-2} \cdot \mathrm{s}^{-1} 0: 100 \mathrm{red}: \mathrm{blue}$ endof-production (EOP) SL from 3 to $14 \mathrm{~d}$ after initiation of EOP lighting treatments.

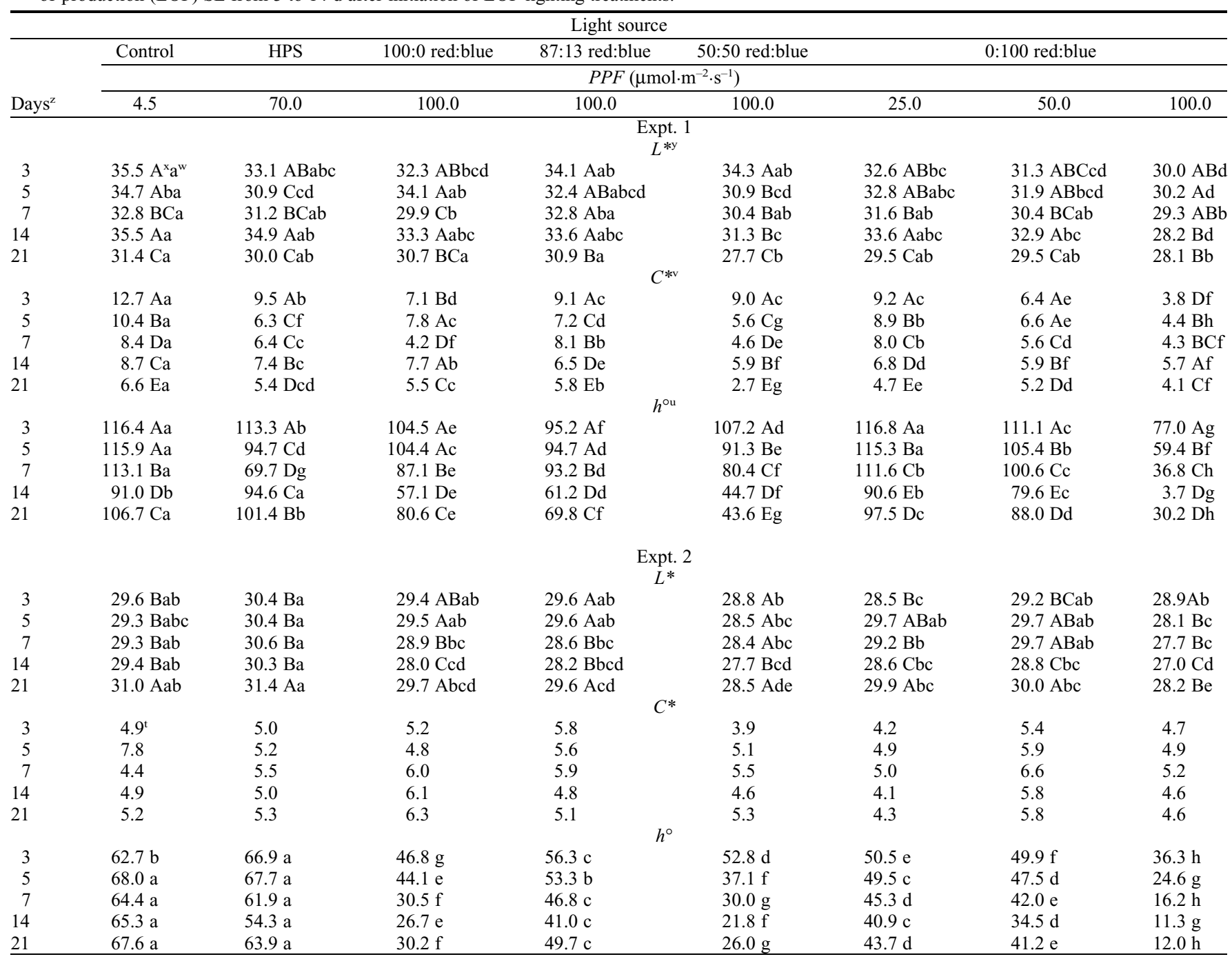

$P P F=$ photosynthetic photon flux.

${ }^{\mathrm{z}}$ Days of exposure to the control or EOP SL.

${ }^{y}$ Leaf lightness $\left(\mathrm{L}^{*}\right)$ indicate darkness and lightness (black: $\mathrm{L}^{*}=0$; white: $\mathrm{L}^{*}=100$ ).

${ }^{\mathrm{x}}$ Within-column means followed by different upper case letters are significantly different by Fisher's least significant differences (LSD) at $P \leq 0.05$.

${ }^{\mathrm{w}}$ Within-row means followed by different lower case letters are significantly different by Fisher's LSD at $P \leq 0.05$.

${ }^{\mathrm{v}}$ Chroma $\left(\mathrm{C}^{*}\right)$ calculated by Eq. [1].

${ }^{\mathrm{u}} \mathrm{Hue}$ angle $\left(h^{\circ}\right)$ calculated by Eq. [2].

${ }^{\mathrm{t}}$ Means with no lettering were found to have no significance.

Effects of seasonal DLI on $h^{\circ}$. Hue angle, calculated from $\mathrm{a}^{*}$ and $\mathrm{b}^{*}$ values, of geranium were significantly influenced by EOP SL and days of exposure. Under seasonal DLIs $\leq 9$ and $\geq 11 \mathrm{~mol} \cdot \mathrm{m}^{-2} \cdot \mathrm{d}^{-1}$, the greatest reduction of geranium green foliage color was observed when plants were finished under LED EOP SL providing $100 \mu \mathrm{mol} \cdot \mathrm{m}^{-2} \cdot \mathrm{s}^{-1}$ (Table 3). For example, from 3 to $14 \mathrm{~d}$ of EOP SL delivering $100 \mu \mathrm{mol} \cdot \mathrm{m}^{-2} \cdot \mathrm{s}^{-1}$ provided by $100: 0,87: 13,50: 50$, and $0: 100$ red:blue light under a mean DLI $\leq 9 \mathrm{~mol} \cdot \mathrm{m}^{-2} \cdot \mathrm{d}^{-1}$ decreased $h^{\circ}$ from $85.8^{\circ}$ to $15.2^{\circ}, 92.6^{\circ}$ to $11.8^{\circ}, 73.9^{\circ}$ to $11.8^{\circ}$, and $71.3^{\circ}$ to $8.7^{\circ}$, respectively; as a result, foliage exhibited violet-red to red hues with increased exposure duration. Consistent with these findings, Owen and Lopez (2015) reported a similar trend for lettuce 'Magenta' leaves as $h^{\circ}$ decreased from $20.1^{\circ}$ to $5.9^{\circ}$ after $14 \mathrm{~d}$ of exposure to $100 \mu \mathrm{mol} \cdot \mathrm{m}^{-2} \cdot \mathrm{s}^{-1}$ of $0: 100 \mathrm{red}$ :blue EOP SL. However, in the current study, with a mean DLI $\geq 11 \mathrm{~mol} \cdot \mathrm{m}^{-2} \cdot \mathrm{d}^{-1}, h^{\circ}$ was only influenced by the light quality provided by the EOP SL sources. For instance, $7 \mathrm{~d}$ of EOP SL delivering $100 \mu \mathrm{mol} \cdot \mathrm{m}^{-2} \cdot \mathrm{s}^{-1}$ provided by $100: 0,87: 13,50: 50$, and $0: 100$ red: blue light resulted in $h^{\circ}$ of $81.4^{\circ}, 86.2^{\circ}, 77.7^{\circ}$, and $50.9^{\circ}$, respectively; thus, foliage exhibited yellow-green to orange-red hues. Therefore, increasing DLIs $\geq 11 \mathrm{~mol} \cdot \mathrm{m}^{-2} \cdot \mathrm{d}^{-1}$ may potentially mask the effects of EOP SL when used in the greenhouse to enhance foliage color.
For fountain grass, as exposure to EOP SL increased from 3 to $14 \mathrm{~d}$ under a mean DLI $\leq$ $9 \mathrm{~mol} \cdot \mathrm{m}^{-2} \cdot \mathrm{d}^{-1}, h^{\circ}$ generally decreased (decreased greenness) for all treatments. The greatest reduction of green foliage color was observed when fountain grass was finished under LED EOP SL providing $100 \mu \mathrm{mol} \cdot \mathrm{m}^{-2} \cdot \mathrm{s}^{-1}$, compared with light provided by the control, HPS lamps, or 0:100 red:blue providing 25 or $50 \mu \mathrm{mol} \cdot \mathrm{m}^{-2} \cdot \mathrm{s}^{-1}$ of EOP SL. For example, 3 to $14 \mathrm{~d}$ of EOP SL delivering $100 \mu \mathrm{mol} \cdot \mathrm{m}^{-2} \cdot \mathrm{s}^{-1}$ provided by $100: 0,87: 13,50: 50$, and 0:100 red:blue light decreased $h^{\circ}$ from $104.5^{\circ}$ to $57.1^{\circ}, 95.2^{\circ}$ to $61.2^{\circ}, 107.2^{\circ}$ to $44.7^{\circ}$, and $77.0^{\circ}$ to $3.7^{\circ}$, respectively; thus, fountain grass foliage exhibited violet-red to yelloworange hues after $14 \mathrm{~d}$ of exposure. Increasing 


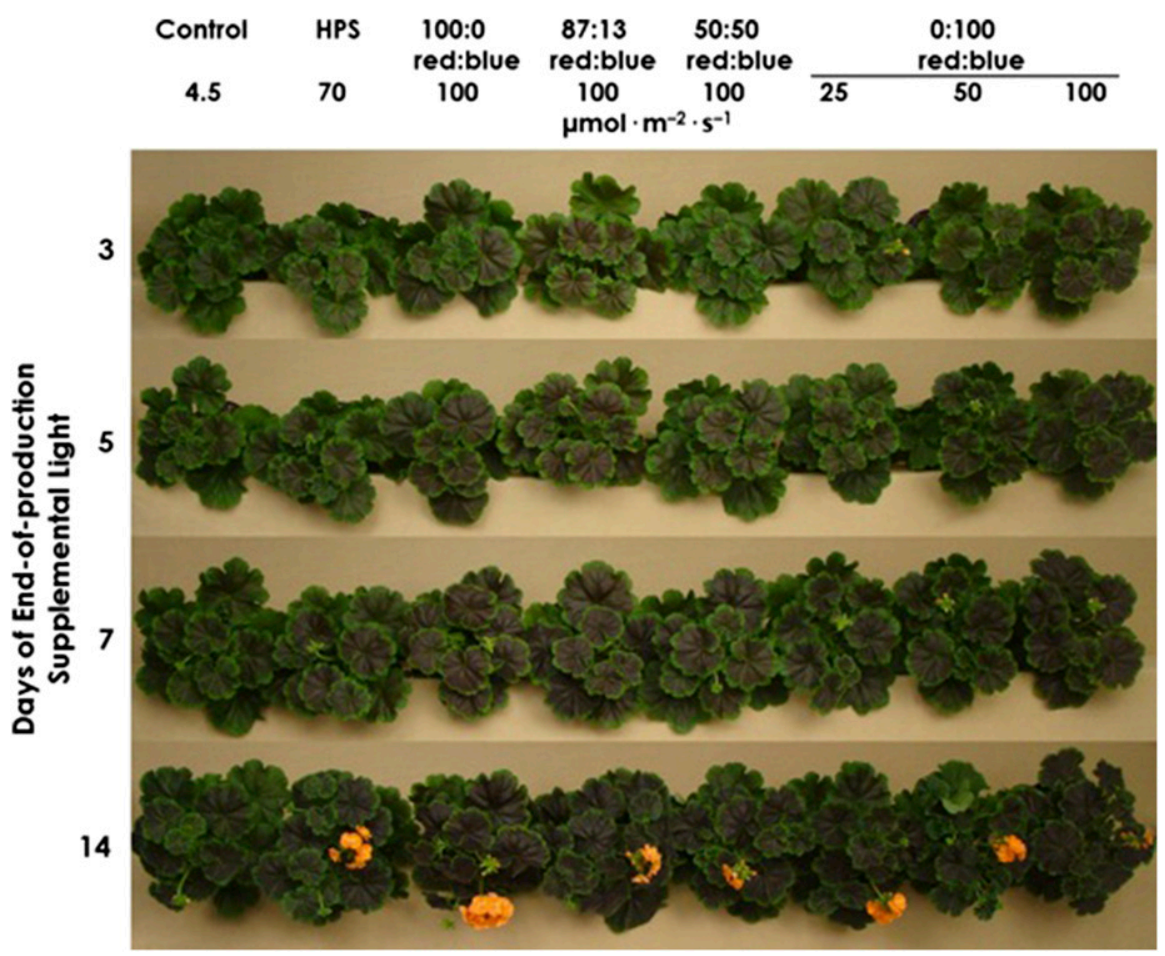

Fig. 2. Leaf color of geranium (Pelargonium $\times$ hortorum 'Black Velvet') finished under 3 to $14 \mathrm{~d}$ of dayextension lighting (control) or end-of-production supplemental lighting from high-pressure sodium (HPS) lamps or light-emitting diodes providing red:blue light ratios (\%) at either low or high intensities.

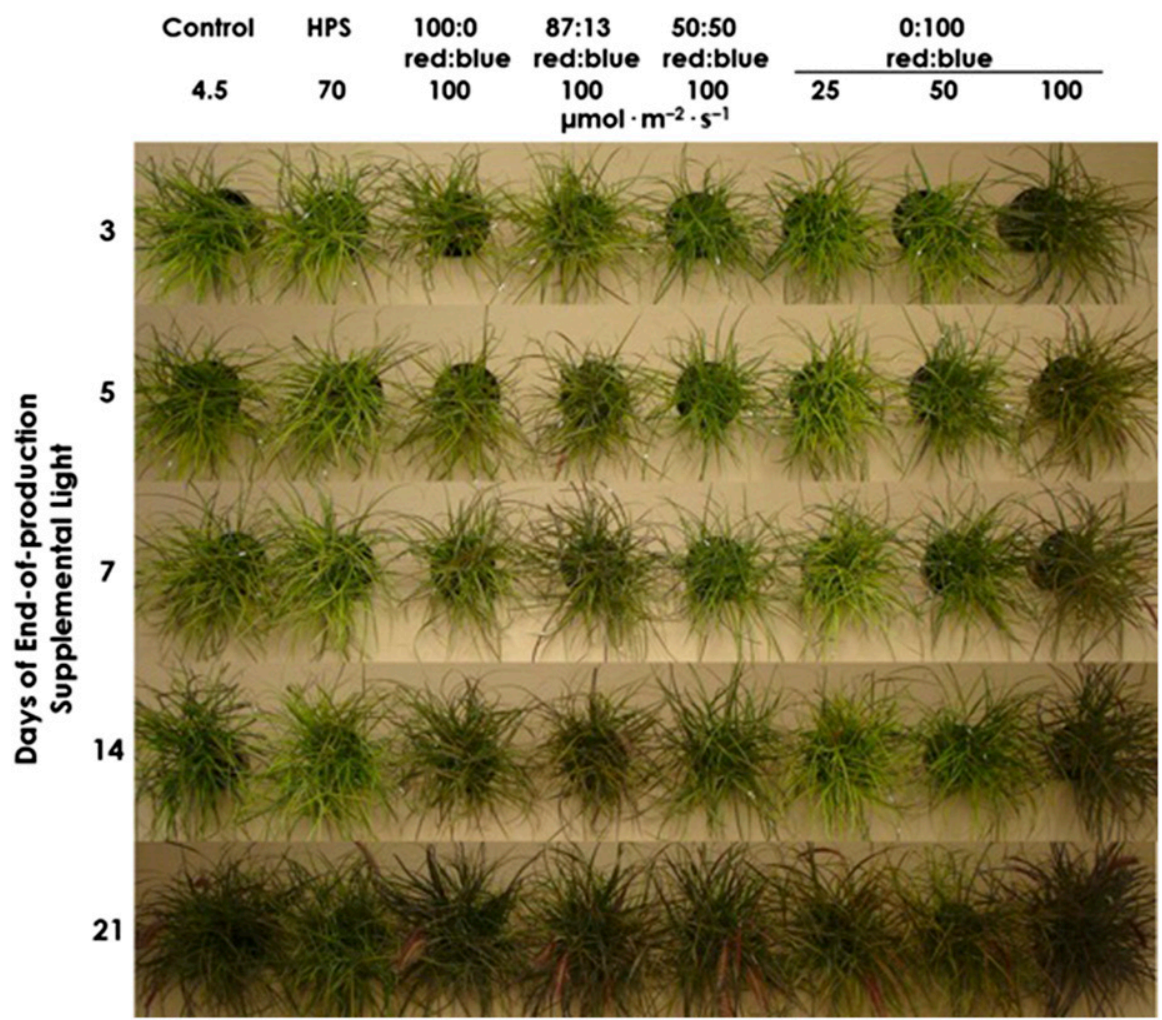

Fig. 3. Leaf color of purple fountain grass [Pennisetum xadvena (formerly known as $P$. setaceum 'Rubrum')] finished under 3 to $21 \mathrm{~d}$ of day-extension lighting (control) or end-of-production supplemental lighting from high-pressure sodium (HPS) lamps or light-emitting diodes providing red:blue light ratios (\%) at either low or high intensities.

intensities of 0:100 red:blue EOP SL also decreased $h^{\circ}$ from 3 to $14 \mathrm{~d}$. For instance, $h^{\circ}$ of fountain grass leaves under 25,50 , or
$100 \mu \mathrm{mol} \cdot \mathrm{m}^{-2} \cdot \mathrm{s}^{-1}$ of $0: 100 \mathrm{red}:$ blue EOP SL decreased from $116.8^{\circ}$ to $90.6^{\circ}, 111.1^{\circ}$ to $76.9^{\circ}$, and $77.0^{\circ}$ to $3.7^{\circ}$ with resulting hues of yellow, yellow-orange, and violet-red, respectively, after $14 \mathrm{~d}$ of exposure (Fig. 3). Likewise, Owen and Lopez (2015) reported 0:100 red:blue EOP SL delivering 25, 50, or $100 \mu \mathrm{mol} \cdot \mathrm{m}^{-2} \cdot \mathrm{s}^{-1}$ for $14 \mathrm{~d}$ reduced $h^{\circ}$ of lettuce 'Ruby Sky' leaves by $48.7^{\circ}, 56.9^{\circ}$, and $112.8^{\circ}$, respectively; thus, resulting in hues of green, green, and red, respectively. Furthermore, Kim et al. (2012) reported increasing DLI $\approx 0.2,0.4,0.8,3.9$, and 7.8 $\mathrm{mol} \cdot \mathrm{m}^{-2} \cdot \mathrm{d}^{-1}(P P F$ of $\approx 2.7,6.8,13.5,67.5$, and $\left.135 \mu \mathrm{mol} \cdot \mathrm{m}^{-2} \cdot \mathrm{s}^{-1}\right)$ provided by triband phosphor fluorescent lamps reduced leaf $h^{\circ}$ of English ivy 'Golden Ingot' and polka dot plant, and thus, resulted in increased red color and variegation. However, in the present study, when fountain grass plants were finished under a mean DLI $\geq 11 \mathrm{~mol} \cdot \mathrm{m}^{-2} \cdot \mathrm{d}^{-1}$, $h^{\circ}$ only differed among EOP SL treatments (Table 4). For instance, $14 \mathrm{~d}$ of EOP SL resulted in reduced $h^{\circ}$ of $11.3^{\circ}$ to $41.0^{\circ}$ under $100 \mu \mathrm{mol} \cdot \mathrm{m}^{-2} \cdot \mathrm{s}^{-1}$ delivered from 100:0, 87:13, 50:50, and 0:100 red:blue light, compared with no EOP SL [control $\left(65.3^{\circ}\right)$ ]. In general, fountain grass foliage exhibited red to yellow-orange hues under LED EOP SL.

Anthocyanins are responsible for the red or purple pigmentation in flowers and leaves. Although anthocyanin content was not determined in the current study, it is well documented that anthocyanin biosynthesis and accumulation is light regulated and dependent on light intensity and quality (Kataoka et al., 2003; Merzlyak and Chivkunova, 2000; Samuoliené et al., 2012). For instance, Beckwith et al. (2004) determined anthocyanin concentration in purple fountain grass, in percent fresh weight, increased as DLI increased from 2.3 to $7.0 \mathrm{~mol} \cdot \mathrm{m}^{-2} \cdot \mathrm{d}^{-1}$ when plants were grown in the greenhouse under ambient solar daylight with SL provided from HPS lamps. In addition, Paradiso et al. (2011) reported the concentration of anthocyanins in leaf tissue of potted rose (Rosa sp. 'Akito') to be higher in reddish leaves ( $52 \pm$ $\left.15 \mu \mathrm{mol} \cdot \mathrm{m}^{-2}\right)$ than in green leaves $(23 \pm$ $10 \mu \mathrm{mol} \cdot \mathrm{m}^{-2}$ ) when grown in a greenhouse receiving SL from HPS lamps providing a DLI of $5.8 \mathrm{~mol} \cdot \mathrm{m}^{-2} \cdot \mathrm{d}^{-1}(P P F$ of 100 $\mu \mathrm{mol} \cdot \mathrm{m}^{-2} \cdot \mathrm{s}^{-1}$ under a $16-\mathrm{h}$ photoperiod). Furthermore, Kim et al. (2012) indicated a correlation between anthocyanin content and CIE L*a*b* values (coloration) in polka dot plant. They reported increasing DLIs from 0.2 to $7.8 \mathrm{~mol} \cdot \mathrm{m}^{-2} \cdot \mathrm{d}^{-1}$, provided by triband phosphor fluorescent lamps, increased anthocyanin content, and thus, resulted in decreased $\mathrm{L}^{*}$ (darker leaves) and increased $\mathrm{a}^{*}$ (increased redness) values in both previously expanded leaved and recently expanded leaves.

Moreover, Wollaeger and Runkle (2013) reported purple pigmentation of young tomato (Solanum lycopersicum L. 'Early Girl') and French marigold (Tagetes patula L. 'Deep Orange') leaves to occur within 2 to $4 \mathrm{~d}$ after placement in a growth chamber under SS LED lighting delivering $10 \%$ blue and $10 \%$ green light, with the remaining light quality percentages consisting of 20:30:30, $0: 80: 0,0: 60: 20,0: 40: 40,0: 20: 60$, and $0: 0: 80$ 
orange:red:hyper-red light providing a DLI of $10.4 \mathrm{~mol} \cdot \mathrm{m}^{-2} \cdot \mathrm{d}^{-1}$. Randall and Lopez (2015) reported similar visual observations of geranium 'Bullseye Red' and French marigold 'Durango Yellow' when seedlings were grown under LED SSL providing 70:30 red: blue light providing an average DLI of 10.6 $\mathrm{mol} \cdot \mathrm{m}^{-2} \cdot \mathrm{d}^{-1}$. Owen and Lopez (2015) also reported enhanced red leaf pigmentation of four lettuce cultivars to occur in as little as $5 \mathrm{~d}$ when plants were finished under ambient solar daylight and $100 \mu \mathrm{mol} \cdot \mathrm{m}^{-2} \cdot \mathrm{s}^{-1}$ of $100: 0$, 0:100, or 50:50 red:blue EOP SL. These findings provide additional support of our observations that exposure to high-intensity LED EOP SL stimulates anthocyanin synthesis and accumulation and, hence, our measured changes in geranium and fountain grass leaf color.

\section{Conclusion}

EOP SL is a cost-effective alternative for finishing high-quality geranium 'Black Velvet' and purple fountain grass plants. The established concept of EOP SL to enhance red leaf lettuce color can be applied to geranium 'Black Velvet' and purple fountain grass to enhance leaf color in 7 to $14 \mathrm{~d}$, respectively, thus increasing aesthetic appeal, quality, and market value. Also, producers that only grow bedding plants in the spring could potentially use this lighting technology for the enhancement of red leaf lettuce in the winter. Our data indicate that bedding plant growers can provide EOP SL with commercially available high-intensity LEDs to increase anthocyanin synthesis and pigmentation of geranium 'Black Velvet' and purple fountain grass plants. Although we addressed two challenging bedding plants, popular for their foliage color, similar results can be expected for other floriculture crops with red or purple pigmented or variegated leaves but further investigations of EOP SL is needed.

\section{Literature Cited}

Beckwith, A.G., Y. Zhang, N.P. Seeram, A.C. Cameron, and M.G. Nair. 2004. Relation of light quality and anthocyanin production in Pennisetum setaceum cvs. Rubrum and Red Riding Hood. J. Agr. Food Chem. 52:456-461.

Berghage, R.D. and D.J. Wolnick. 2000. Consumer color preference in New Guinea impatiens. HortTechnology 10:206-208.

Bergstrand, K.J. and H.K. Schüssler. 2012. Growth and photosynthesis of ornamental plants cultivates under different light sources. Acta Hort. 956:141-147.

Brand, M.H. 1997. Shade influences plant growth, leaf color, and chlorophyll content of Kalmia latifolia L. cultivars. HortScience 32:206-208.
Chalker-Scott, L. 1990. Environmental significance of anthocyanins in plant stress responses. J. Photochem. Photobiol. B 70:1-9.

Currey, C.J. and J.E. Erwin. 2011. Photosynthetic daily light integral impacts growth and flowering of several Kalanchoe species. HortTechology $21: 98-102$.

Faust, J.E. 2011. Plant growth responses to daily light integrals, p. 84-89. In: J. Nau (ed.). Ball redbook. 18 ed., Vol. 2: Light. Ball Publishing, West Chicago, IL.

Faust, J.E., V. Holcombe, N.C. Rajapakse, and D.R. Layne. 2005. The effect of daily light integral on bedding plant growth and flowering. HortScience 40:645-649.

Gangadhar, B.H., R.K. Mishra, G. Pandian, and S.W. Park. 2012. Comparative study of color, pungency, and biochemical composition in chili pepper (Capsicum annuum) under different light-emitting diode treatments. HortScience 47:1729-1735.

Garland, K.F., S.E. Burnett, L.B. Stack, and D. Zhang. 2010. Minimum daily light integral for growing high-quality coleus. HortTechnology 20 : 929-933.

Gazula, A., M.D. Kleinhenz, J.C. Scheerens, and P.P. Ling. 2007. Anthocyanin levels in nine lettuce (Lactuca sativa) cultivars: Influence of planting date and relations among analytic, instrumented, and visual assessment of color. HortScience 42:232-238.

Hanan, J.J. 1998. Radiation, p. 91-166. In: Greenhouses: Advanced technology for protected horticulture. CRC Press, Inc., Boca Raton, FL.

Islam, M.A., G. Kuwar, J.L. Clarke, D.R. Blystad, H.R. Gislerød, J.E. Olsen, and S. Torre. 2012. Artificial light from light emitting diodes (LEDs) with a high portion of blue light results in short poinsettias compared to high pressure sodium (HPS) lamps. Sci. Hort. 147:136-143.

Kataoka, I., A. Sugiyama, and K. Beppu. 2003. Role of ultra violet radiation in accumulation of anthocyanin in berries of 'Gros Colman' grapes (Vitis vinifera L.). J. Jpn. Soc. Hort. Sci. 72:1-6.

Kim, J., S.W. Kong, C.H. Pak, and M.S. Kim. 2012. Changes in leaf variegation and coloration of English ivy and polka dot plant under various indoor light intensities. HortTechnology 22:49-55.

Korczynski, P.M., J. Logan, and J.E. Faust. 2002. Mapping monthly distribution of daily light integrals across the contiguous United States. HortTechology 12:12-16.

Lightbourn, G.J., R.J. Griesbach, J.A. Novotny, B.A. Clevidence, D.D. Rao, and J.R. Stommel. 2008. Effects of anthocyanin and carotenoid combinations on foliage and immature fruit color of Capsicum annuum L. J. Hered. 99: $105-111$.

Madeira, A.C., A. Ferreira, A. de Varennes, and M.I. Vieira. 2003. SPAD meter versus tristimulus colorimeter to estimate chlorophyll content and leaf color in sweet pepper. Commun. Soil Sci. Plant Anal. 34:2461-2470.

Merzlyak, M.N. and O.B. Chivkunova. 2000. Light-stress-induced pigment changes and evidence for anthocyanin photoprotection in apples. J. Photochem. Photobiol. B 55:155-163.
Nguyen, P. and V.D. Cin. 2009. The role of light on foliage colour development in coleus (Solenostemon scutellarioides (L.) Codd). Plant Physiol. Biochem. 47:934-945.

Oren-Shamir, M. 2009. Does anthocyanin degradation play a significant role in determining pigment concentration in plants? Plant Sci. 177:310-316.

Owen, W.G. and R.G. Lopez. 2015. End-ofproduction supplemental lighting with red and blue light-emitting diodes (LEDs) influences red pigmentation of four lettuce varieties. HortScience 50:676-684.

Paradiso, R., E. Meinen, J.F.H. Snel, P. De Visser, W. Van Ieperen, S.W. Hogewoning, and L.F.M. Marcelis. 2011. Spectral dependence of photosynthesis and light absorption in single leaves and canopy of rose. Sci. Hort. 127:548554.

Peet, M.M. 1999. Greenhouse crop stress management. Acta Hort. 481:643-654.

Randall, W.C. and R.G. Lopez. 2015. Comparison of bedding plant seedlings grown under solesource light-emitting diodes (LEDs) and greenhouse supplemental lighting from LEDs and high-pressure sodium lamps. HortScience 50:705-713.

Samuoliené, G., R. Sirtautas, A. Brazaityté, and P. Duchovskis. 2012. LED lighting and seasonality effects antioxidant properties of baby leaf lettuce. Food Chem. 134:1494-1499.

Schamp, B., E. Pauwels, and B. Gobin. 2012. Developing LED light recipes for multilayering systems: LED as an alternative for HPS in forcing of Rhododendron simsii. Acta Hort. 956:121-128.

Seigler, D. 1998. Plant secondary metabolism. Kluwer Academic Publishers, Dordrecht, The Netherlands.

Tarakanov, I., O. Yakovleva, I. Konovalova, G. Paliutina, and A. Anisimov. 2012. Lightemitting diodes: On the way to combinatorial lighting technologies for basic research and crop production. Acta Hort. 956:171-178.

Terfa, M.T., M.S. Poudel, A.G. Roro, H.R. Gislerød, J.E. Olsen, and S. Torre. 2013. Light emitting diodes with a high proportion of blue light affects external and internal quality parameters of pot roses differently than the traditional high pressure sodium lamp. Acta Hort. 956:635-641.

Wang, Q., J. Chen, R.H. Stamps, and Y. Li. 2005. Correlation of visual quality grading and SPAD reading of green-leaved foliage plants. J. Plant Nutr. 28:1215-1225.

Warren, W.J., D.W. Hand, and M.A. Hannah. 1992. Lighting interception and photosynthetic efficiency in some glasshouse crops. J. Expt. Bot. 43:363-373.

Werner, J., Y. Okada, and M. Karlsson. 2011. Using light emitting diodes in high latitude greenhouse production. Acta Hort. 907:287290.

Wollaeger, H.M. and E.S. Runkle. 2013. Growth responses of ornamental annual seedlings under different wavelengths of red light provided by light-emitting diodes. HortScience 48:1478-1483. 